\title{
PENERAPAN MODEL PEMBELAJARAN KOOPERATIF TIPE MIND MAPPING UNTUKMENINGKATKAN HASIL BELAJAR IPS PADA MATERI POKOK KOPERASI DI KELAS IV SDN13 POASIA KENDARI
}

\author{
Ni Kadek Trisnawati ${ }^{1)}$, La Anse ${ }^{1}$, La Ode Rafiuddin ${ }^{1)}$ \\ ${ }^{1)}$ Jurusan Pendidikan Guru Sekolah Dasar \\ FKIP Universitas Halu Oleo \\ e-mail: Trisnawatinikadek@yahoo.co.id
}

\begin{abstract}
Abstrak: Penelitian ini bertujuan untuk Meningkatkan hasil belajar siswa pada Materi koperasi di kelas $\mathrm{IV}_{\mathrm{B}}$ SDN 13 Poasia melalui model pembelajaran kooperatif tipe mind mapping pada tahun ajaran 2015/2016. Penelitian ini dilaksanakan pada semester genap tahun pelajaran 2015/2016. Penelitian ini dilaksanakan di kelas $\mathrm{IV}_{\mathrm{B}}$ SD Negeri 13 Poasia dengan jumlah siswa 24 orang yang terdiri dari 10 orang laki-laki dan 14 orang perempuan. Penelitian ini dilaksanakan mulai tanggal 6 Januari 2016 s/d 30 Januari 2016. Pelaksanaan penelitian tindakan kelas ini terdiri dari 2 (dua) siklus yaitu siklus I dan Siklus II. Adapun prosedur dalam penelitian ini adalah: 1) Perencanaan, 2) Pelaksanaan Tindakan, 3) Observasi dan Evaluasi, 4) Refleksi. Sumber data pada penelitian ini adalah guru sebagai peneliti dan siswa kelas $\mathrm{IV}_{\mathrm{B}}$ SD Negeri 13 Poasia. Teknik analisis data dalam penelitian ini adalah statistik deskriptif. Hasil yang diperoleh yang berkaitan dengan hasil belajar siswa pada siklus I 66,66 \% atau sebanyak 16 orang dari 24 siswa yang tuntas memperoleh nilai $\geq 70$ dengan nilai rata-rata 68,83 . Aktivitas guru pada siklus I pertemuan II pada materi yang perbedaan koperasi dengan badan usaha lain $88,33 \%$. dan pada siklus II pertemuan 2 pada materi perbedaan koperasi dan macam-macam koperasi meningkat menjadi $87,5 \%$ atau sebanyak 21 orang dari 24 siswa yang tuntas memperoleh nilai $\geq 70$ dengan nilai rata-rata 80,25 .
\end{abstract}

Kata kunci: Hasil Belajar, Model Pembelajaran Kooperatif Tipe Mind Mapping

Abstract: This research aims to improve students' achievement at subject material cooperative society in $\mathrm{IV}_{\mathrm{B}}$ SDN 13 Poasia Kendari by using cooperative learning model mind mapping type in 2015/2016 academic year. This research conducted in the second semester 2015/2016 academic year. This research conducted at class $\mathrm{IV}_{\mathrm{B}}$ of elementary school 13 Poasia in with 24 students consist of 10 male and 14 female. The research started from $06^{\text {th }}$ january 2016 and finish on $30^{\text {th }}$ january 2016 . This research consist of two cycles that is first cycle and second cycle. There is procedure even this research is: first) planning, second) action performing, third) observation and evaluation, and the last) reflection. Data Source in this research are teacher as the researcher and students IV $^{\mathrm{B}}$ SDN 13 Poasia. The technique of data analysis in this research is descriptive statistic. Acquire result that related with students' achievement at first cycle $66,66 \%$ or as much 16 students from 24 students that passed get point $\geq 70$ mean 68,83 . Teacher activities at first cycle in second meeting get $83,33 \%$ and at the second cycle in the second meeting improve to $87,5 \%$ or as much 21 from 24 students that get point $\geq 70$ mean 80,25 .

Keyword: Results Of Study, Cooperative Learning Model Mind Mapping Type. Cooperative Society

\section{Pendahuluan}

Istilah ilmu pengetahuan sosial ips yang secara umum resmi mulai dipergunakan di Indonesiasejak tahun 1975 adalah istilah indonesia untuk pengertian sosial studies seperti di amerika serikat, Sardjiyo (2007:1.21)

Dalam proses pendidikan peran dan fungsi guru sangat menentukan aktivitas belajar siswa yang berdampak pada keberhasilan pelaksanaan proses pembelajaran. Di samping itu, sebagai seorang pengajar guru harus mampu memperhatikan berbagai teknik yang tepat untuk dapat menyajikan materi pembelajaran yang baik.Berbagai teknik yang dimaksud diantaranya adalah metode, strategi, model, serta aktivitas belajar siswa. Karena hasil akhir dari kegiatan ini adalah meningkatkan kegiatan pembelajaran menuju tercapainya hasil belajar yang optimal. 
Proses pembelajaran di kelas cenderung pada pencapaian target kurikulum, lebih mementingkan pada penghafalan konsep bukan pada pemahaman. Dalam pencapaian materi biasanya guru hanya menggunakan metode ceramah, siswa hanya duduk, mencatat, dan mendengar apa yang disampaikan dan sedikit peluang bagi siswa untuk bertanya. Dengan demikian suasana menjadi tidak kondusif sehingga siswa menjadi pasif.

Berdasarkan observasi yang dilakukan peneliti pada proses pembelajaran yang terjadi di kelas $\mathrm{IV}_{\mathrm{B}}$ SD Negeri 13 Poasia adalah pembelajaran yang berpusat pada guru. Guru menyampaikan materi pelajaran dengan menggunakan metode ceramah atau ekspositori dengan lebih mengaktifkan guru, sedangkan siswa kurang aktif dalam kegiatan pembelajaran. Sehingga hasil belajar siswa terhadap materi koperasi tahun ajaran 2014/2015 semester genap menunjukan bahwa dari 23 siswa, hanya 8 siswa atau $34,78 \%$ yang mencapai kriteria ketuntasan minimal (KKM) yang ditetapkan sekolah yaitu 70. Rendahnya hasil belajar siswa tersebut dikarenakan kurangnya pemahaman siswa pada materi IPS. Salah satu faktor yang menyebabkan kurangnya pemahaman siswa tersebut dikarenakan siswa kurang aktif dan kurang bersemangat dalam proses pembelajaran. Dimana dalam pembelajaran, aktivitas siswa lebih banyak pada kegiatan mendengarkan penjelasan guru dan mencatat. Sementara itu kebanyakan guru dalam mengajar masih kurang memperhatikan kemampuan berpikir siswa dan metode mengajar yang digunakan kurang bervariasi. Hal inilah yang mengakibatkan pola belajar siswa cenderung menghafal, serta kemampuan berpikir dan daya analisis siswa kurang berkembang. Peserta didik lebih cenderung menghafal dari pada memahami materi yang diajarkan oleh guru

Berdasarkan uraian latar belakang di atas, maka masalah yang diangkat dalam penelitian ini adalah Apakah penerapan model pembelajaran Kooperatif Tipe Mind Mapping dapat meningkatkan hasil belajar siswa pada Materi koperasi kelas IV SDN 13 poasia Penelitian ini bertujuan Meningkatkan hasil belajar siswa pada Materi koperasi di kelas IV $_{\mathrm{B}}$ SDN 13 Poasia melalui model pembelajaran kooperatif tipe mind mapping pada tahun ajaran 2015/2016

\section{Metode penelitian}

Jenis Penelitian

Jenis penelitian yang digunakan dalam penelitian ini adalah penelitian tindakan kelas. Penelitian tindakan kelas adalah penelitian yang dilaksanakan oleh guru di dalam kelas. Ciri-ciri khusus dari penelitian tindakan kelas yaitu: 1) penelitian tindakan kelas dilaksanakan oleh guru itu sendiri, 2) penelitian tindakan kelas berangkat dari permasalahan nyata di kelas, 3) penelitian tindakan kelas mempersyaratkan adanya tindakan yang berlanjut untuk memperbaiki proses pembelajaran, 4) adanya refleksi diri.

Setting Penelitian

Penelitian ini dilaksanakan di SD Negeri 13 Poasia pada kelas $\mathrm{IV}_{\mathrm{B}}$ semester genap tahun pelajaran 2015/2016.

Subjek Penelitian

Subjek dalam penelitian ini adalah guru sebagai peneliti dan siswa kelas $\operatorname{IV}_{\mathrm{B}}$ SD Negeri 13 Poasia Kota Kendari dengan jumlah siswa 24 orang yang terdiri dari 10 siswa laki-laki dan 14 siswa perempuan.

\section{Prosedur Penelitian}

Prosedur dalam penelitian ini adalah sesuai dengan langkah-langkah PTK yaitu perencanaan, pelaksanaan tindakan, observasi, evaluasi dan refleksi.

Tekhnik Analisis Data

Jenis data dalam penelitian ini adalah data kualitatif dan data kuantitatif. Data kualitatif berupa kegiatan proses pembelajaran yang dilaksanakan oleh guru dan juga aktivitas siswa dalam mengikuti proses pembelajaran dan data kuantitatif berupa tes hasil belajar siswa. Data kualitatif digunakan untuk menghimpun data tentang pelaksanaan proses pembelajaran yang dilaksanakan oleh guru. Untuk memperoleh data kualitatif digunakan lembar observasi. Data kuantitatif diperoleh melalui tes. Data kuantitatif, yaitu berupa hasil belajar, diambil melalui tes tertulis dalam bentuk essay pada setiap akhir siklus. Analisis data yang digunakan dalam Penelitian Tindakan Kelas (PTK) ini adalah menggunakan statistik deskriptif untuk menghitung nilai siswa, rata-rata nilai siswa, ketuntasan belajar, keberhasilan 
aktivitas mengajar guru dan keberhasilan aktivitas belajar siswa. Langkah-langkah analisis data adalah sebagai berikut:

a. Menentukan nilai siswa ditentukan skor yang diperoleh siswa pada tes yang dilakukan dengan rumus :

Nilai Siswa $=\frac{\text { Skor perolehan }}{\text { Skor Maksimum }} \times 100$

b. Menentukan Rata - rata Nilai Siswa

Nilai Rata-rata siswa $=\frac{\text { Jumlah nilai seluruh siswa }}{\text { Jumlah siswa }}$

(Kusumah, 2012, p.157)

c. Menentukan ketuntasan aktivitas belajar siswa

$\% \mathrm{KABS}=\frac{\text { Jumlah perolehan siswa }}{\text { Jumlah skor maksimum }} \times 100 \%$

Keterangan: \% KABS = Persentase ketuntasan aktivitas belajar siswa

d. Menentukan ketuntasan aktivitas mengajar guru

$\% \mathrm{KAMG}=\frac{\text { Jumlah perolehan guru }}{\text { Jumlah skor maksimum }} \times 100 \%$

Keterangan : \% KAMG = Persentase ketuntasan aktivitas mengajar guru

(Kurniasih, 2014, p.43).

e. Menghitung persentase ketuntasan secara klasikal dengan menggunakan rumus sebagai berikut :

$\%$ tuntas $=\frac{\sum x i}{\sum f i} \times 100 \%$

Dengan:

$\sum x i=$ Jumlah siswa pada kategori ketuntasan

$\sum f i=$ Jumlah siswa secara keseluruhan

(Hamid, 2007, p. 4.2).

Indikator kinerja dalam penelitian ini adalah indikator tentang keterlaksanaan skenario pembelajaran dan indikator peningkatan hasil belajar IPS siswa dalam penelitian ini. Setiap siswa dikatakan tuntas belajarnya (ketuntasan individu) jika proposisi jawaban benar siswa $\geq 65 \%$. Suatu kelas dikatakan tuntas belajarnya (secara klasikal) jika dalam kelas tersebut $\geq 80 \%$ siswa yang telah tuntas belajarnya sesuai dengan KKM yang telah ditetapkan sekolah. Ketuntasan aktivitas mengajar guru dan ketuntasan aktivitas belajar siswa dianggap berhasil apabila dalam pelaksanaan pembelajaran skenario pembelajaran mencapai minimal $80 \%$ dari keseluruhan skenario pembelajaran (Depdikbud dalam Trianto, 2013, p.241)

\section{Hasil Penelitian}

Sedangkan hasil observasi aktivitas belajar siswa pada siklus I pertemuan pertama menunjukkan bahwa skor yang diperoleh adalah 7sedangkan skor maksimum adalah 12. Persentase keberhasilan aktivitas belajar siswa diperoleh dari perbandingan antara skor perolehan dari aktivitas belajar siswa dan skor maksimum dikalikan seratus persen, maka persentase keberhasilan aktivitas belajar siswa pertemuan pertama adalah 58,33\%. Pada pertemuan kedua siklus I menunjukkan skor yang diperoleh dari aktivitas belajar siswa adalah 9 sedangkan skor maksimum 12. Maka persentase keberhasilan aktivitas belajarsiswa pada pertemuan kedua adalah $66,66 \%$.

Berdasarkan tes yang dilakukan menunjukan bahwa hasil belajar.Ips siswa setelah menerapkan model pembelajaran kooperatif tipe mind mapping khususnya pada materi koperasi hasil tes menunjukan bahwa hanya beberapa siswa belum yang mencapai nilai $\geq 70$. Dari 24 siswa kelas $\operatorname{IV}_{\mathrm{B}}$ yang memperoleh nilai $\geq 70$ sebanyak 8 siswa atau dengan persentase 33,33\% siswa yang belum mencapai KKM, sedangkan yang memperoleh nilai $\geq 70$ sebanyak 16 siswa atau dengan persentase $66,66 \%$. dengan nilai rata-rata 68,83 . 
Berdasarkan hasil observasi pada siklus I, guru dan siswa telah melakukan sebagian kegiatan pembelajaran dengan baik. Namun demikian, masih terdapat kekurangan-kekurangan yang perlu diperbaiki antara lain, pada pertemuan pertama guru belum mampu mengorganisasikan waktu dengan baik. Guru juga sudah terlalu jauh dalam memberikan bimbingan kepada siswa atau kelompok yang mengalami kesulitan dalam menyelesaikan penjumlahan pecahan yang berpenyebut tidak sama sehingga menyebabkan kelompok lain masih terabaikan.

Berdasarkan hasil tes belajar siswa pada siklus I, siswa yang memperoleh nilai $\geq 70$ sebanyak 16 orang siswa atau sebesar $66,66 \%$ dengan nilai rata-rata 68,83 . belum mencapai target yaitu $80 \%$. hasil belajar Ips siswa pada siklus I yang belum memenuhi indikator keberhasilan dalam penelitian ini, maka penelitian ini dilanjutkan pada tindakan siklus II.

Hasil observasi kegiatan mengajar guru pada siklus II pertemuan pertama menunjukkan bahwa skor perolehan guru adalah 9 sedangkan skor maksimum 11. Persentase keberhasilan aktivitas mengajar guru diperoleh dari perbandingan antara skor perolehan guru dan skor maksimum dikalikan seratus persen, maka persentase keberhasilan aktivitas mengajar guru

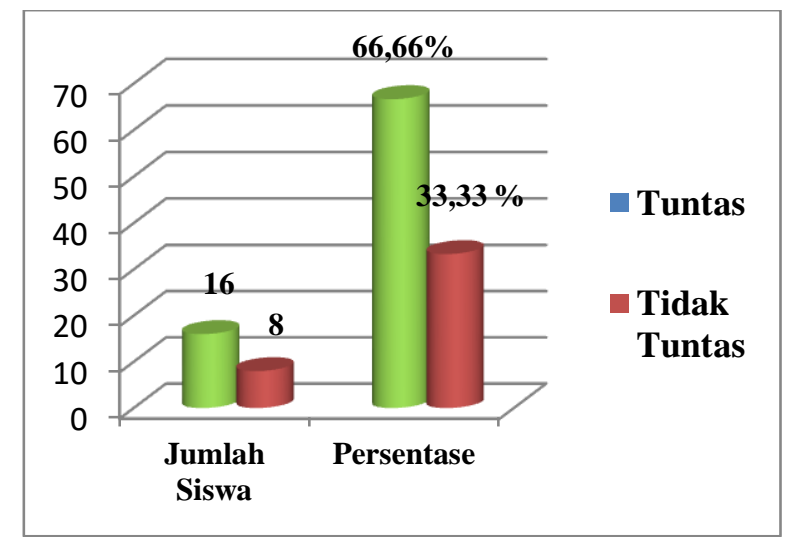

Pertemuan pertama adalah $81,81 \%$. Pada pertemuan kedua siklus II menunjukkan bahwa skor perolehan guru adalah 10 sedangkan skor maksimum 11. Maka persentase keberhasilan aktivitas mengajar guru pertemuan kedua adalah 90,90\%.

Sedangkan hasil observasi aktivitas belajar siswa pada siklus II pertemuan pertama menunjukkan bahwa skor yang diperoleh adalah 9 sedangkan skor maksimum adalah 12. Persentase keberhasilan aktivitas belajar siswa diperoleh dari perbandingan antara skor perolehan dari aktivitas belajar siswa dan skor maksimum dikalikan seratus persen, maka persentase keberhasilan aktivitas belajar siswa pertemuan pertama adalah $75 \%$. Pada pertemuan kedua siklus II menunjukkan skor yang diperoleh dari aktivitas belajar siswa adalah 10 sedangkan skor maksimum 12. Maka persentase keberhasilan aktivitas belajar siswa pada pertemuan kedua adalah 83,3\%.

Berdasarkan hasil tes yang pada pelaksanaan pembelajaran yang dilakukan oleh guru sudah mencapai indikator dalam penelitian yaitu $80 \%$. Hasil belajar Ips secara klasikal yang memperoleh nilai $\geq 70$ sebanyak21 siswa atau dengan persentase $87,5 \%$ siswa mencapai KKM, sedangkan yang memperoleh nilai $\geq 70$ sebanyak 3 siswa atau dengan persentase 12,5\%, dengan rata-rata 80,25

Hasil analisis ketuntasan belajar siswa pada penelitian hasil belajar secara klasikal dapat dilihat pada tabel berikut ini:

\section{Tabel 1. Analisis Ketuntasan Hasil Belajar Siswa Pada Siklus II}

\begin{tabular}{ccccc}
\hline No & Ketuntasan & Skor & Jumlah siswa & Persentase (\%) \\
\hline 1 & Tuntas & $65-100$ & 21 & $87,5 \%$ \\
2 & Belum Tuntas & $0-64$ & 3 & $12,5 \%$ \\
& Total & & 24 & $100 \%$
\end{tabular}




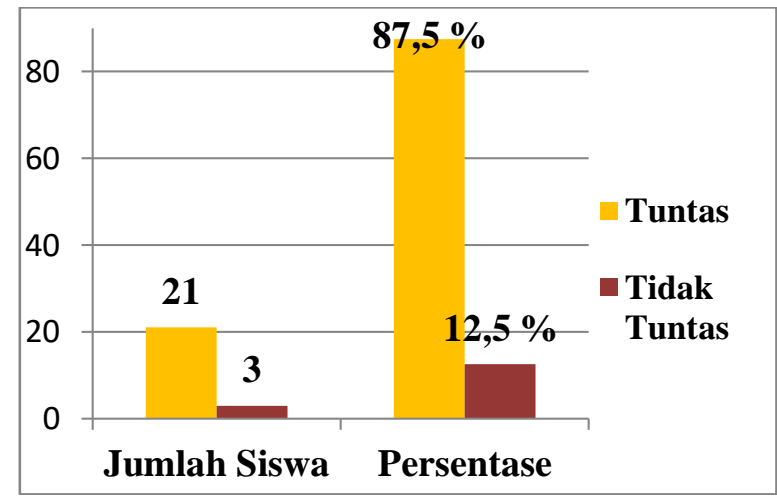

Ketercapaian aktivitas guru dan siswa dalam proses pembelajaran pada siklus II yaitu pertemuan pertama aktivitas guru sebesar $81,81 \%$ dan pertemuan kedua meningkat menjadi $90,90 \%$. Sedangkan aktivitas belajar siswa siklus II yaitu pertemuan pertama sebesar $75 \%$ dan pertemuan kedua meningkat menjadi $83,3 \%$.

Berdasarkan hasil tes belajar siswa pada siklus II, siswa yang memperoleh nilai $\geq 70$ sebanyak 21 orang siswa atau sebesar 87,5\% dengan nilai rata-rata 80,25. Secara klasikal mencapai persentase ketuntasan yaitu $87,5 \%$ telah mencapai target yaitu $80 \%$.

Dari hasil tes belajar siswa yang diperoleh pada siklus II, dapat dikatakan bahwa penerapan model pembelajaran kooperatif tipe mind mapping memberikan dampak yang positif terhadap hasil belajar siswa. Sejalan dengan pendapat Nawawi dan K.Brahim 2007, dalam Ahmad Susanto (2015:5) hasil belajar dapat di artikan sebagai tingkat keberhasilan siswa dalam mempelajari materi pelajaran di sekolah yang dinyatakan dalam skor yang diperoleh dari hasil tes mengenal sejumlah materi pelajaran tertentu. Karena indikator keberhasilan dalam penelitian ini telah tercapai, dalam hal ini minimal $80 \%$ siswa telah mencapai nilai $\geq 70$, maka penelitian ini dihentikan sampai pada siklus II. Ini berarti bahwa, hipotesis tindakan telah terjawab yaitu dengan melalui penerapan model pembelajaran kooperatif tipe mind mapping hasil belajar siswa pada materi koperasi kelas $\mathrm{IV}_{\mathrm{B}} \mathrm{SD}$ Negeri 13 Poasia dapat ditingkatkan.

\section{Pembahasan}

Menurut Nawawi dan K.Brahim 2007, dalam Ahmad Susanto (2015:5) hasil belajar dapat di artikan sebagai tingkat keberhasilan siswa dalam mempelajari materi pelajaran di sekolah yang dinyatakan dalam skor yang diperoleh dari hasil tes mengenal sejumlah materi pelajaran tertentu.

Berdasarkan nilai diperoleh siswa guru melakukan analisis untuk menentukan ketuntasan belajar siswa. Hasil analisis ketuntasan belajar siswa pada siklus I dan siklus II dideskripsikan bahwa pada pembelajaran siklus I, siswa memperoleh antara 0-64 berjumlah 8 orang siswa (45,5\%), siswa memperoleh nilai rentang 65-100 berjumlah 16 orang siswa $(66,66 \%)$, pada pembelajaran siklus II, siswa yang memperoleh nilai 0 -64berjumlah 3 orang $(33,33 \%)$ siswa yang memperoleh nilai rentang 65-100 berjumlah 21 orang $(87,5 \%)$.Ketuntasan belajar siswa mencapai $87,5 \%$ dimana siswa yang memperoleh nilai $\geq 70$ berjumlah 21 orang sedangkan 3 orangsiswa yang belum mencapai ketuntasan .

Wahyudin (2007:35) mengemukakan bahwa keberhasilan dalam proses pembelajaran dititik beratkan pada peserta didik dan guru, dimana peserta didik haruslah dapat meningkatkan kesiapan dan kesungguhan dalam proses pembelajaran untuk mencapai prestasi belajar yang diharapakan dan guru sebagai pendidik dapat mengantarkan anak didiknya pada tujuan yang telah ditetapkan.

Selama proses pembelajaran peneliti mengadakan refleksi dengan obsever untuk mengetahui kelemahan dan keberasilan dalam proses pembelajaran. Hal- hal yang observasi aktivitas mengajar guru dan aktivitas belajar siswa pada proses pembelajaran. Hasil observasi aktivitas mengajar guru pada pneliti tindakan pembelajaran menjadi dasar untuk menentukan skor pemerolehan guru, skor pemerolehan guru digunakan untuk persentase keberasilan aktivitas mengajar guru.

Dengan adanya kekurangan-kekurangan yang terjadi pada tindakan siklus1, sehingga KAMG pada tindakan 1 pertemuan 1 hanya mencapai 63,63\% dari keseluruhan kegiatan pembelajaran dan pada kedua hanya mencapai $72,7 \%$. Sebelum melaksanakan penelitian pada tindakan II peneliti 
mengadakan refleksi bersama obsever untuk memperbaiki kekurangan-kekurangan pada tindakan siklus I.

Pada pelaksanaan tindakan II, keberasilan aktivitas mengajar guru dan aktivitas belajar siswa sudah mengembirakan bagi peneliti, menurut hasil observasi pelaksanaan skenario pembelajaran pada pertemuan pertama aktivitas guru mencapai $81,81 \%$ dan pada pertemuan kedua telah mencapai $90,90 \%$, semua skenario dalam pembelajaran telah terlaksana dengan baik.

Ciri model pembelajaran kooperatif yang dikemukakan oleh Trianto (2013:56) menjelaskan bahwa dalam pembelajaran kooperatif siswa belajar bersama dalam kelompok-kelompok kecil yang terdiri dari 4-6 orang siswa yang sederajat tetapi heterogen, kemampuan, jenis kelamin, suku/ras, dan satu sama lain saling membantu. Tujuan dibentuknya kelompok tersebut adalah untuk memberikan kesempatan kepada semua siswa untuk dapat saling bekerjasama dan saling membantu untuk memahami materi, sehingga siswa selain mempunyai tanggung jawab individu juga mempunyai tanggung jawab kelompok.

Menurut Adrian (2010:7), dalam belajar sangat dituntut keaktifan siswa. Siswa yang lebih banyak melakukan kegiatan sedangkan guru lebih banyak membimbing dan mengarahkan. Berhasil atau gagalnya pencapaian tujuan pendidikan sangat bergantung pada proses belajar yang dialami siswa, baik ketika berada di sekolah maupun di lingkungan rumah atau keluarga sendiri. Sejalan dengan itu, Winkel dalam Adrian (2010:7) mengatakan bahwa prestasi belajar adalah suatu bukti keberhasilan belajar atau kemampuan seseorang siswa dalam melakukan kegiatan belajarnya sesuai dengan bobot yang dicapainya.

Persentase keberasilan aktivitas belajar siswa pada siklus 1 pertemuan pertama adalah 58,33\% dan pertemuan kedua $66,66 \%$ persentase keberasilan aktivitas siswa pada siklus II pertemuan pertama meningkat menjadi $75 \%$ dan pertemuan kedua $83,3 \%$.

Ketuntasan belajar siswa mengidentifikasi bahwa indikator keberasilan peneliti yang di tetapkan telah tercapai, sedangkan hasil observasi terhadap pelaksanaan pemelajaran dikatakan sempurna, yakni seluruh komponen dalam skenario pembelajaran telah dilaksanakan dengan hasil sesuai harapkan.karena semua indikator telah tercapai, maka hipotesis tindakan telah tercapai yakni penerapan model pembelajaran mind mapping dapat meningkatkan hasil belajar IPS siswa pada materi koperasi di kelas IV 13 poasia kendari.

Dari hasil evaluasi tersebut bahwa usaha dan keberasilan belajar dipengaruhi oleh berbagai faktor. Hal ini sesuai dengan yang dikemukakan oleh oleh Syah (2010:132) bahwa belajar dipengaruhi oleh beberapa faktor yaitu faktor internal adalah faktor yan berasal diri siswa,faktor eksternal adalah faktor yang berasal dari luar diri siswa dan faktor pendekatan pembelajaran yaitu jenis upaya belajar yang meliputi strategi dan metode yang digunakan untu melakukan pembelajaran.

Karena indikator keberasilan dalam penelian telah tercapai dalam hal ini aktivitas belajar siswa selama proses pembelajaran sudah cukup baik dan minimal 75\% siswa telah memperoleh nilai $\geq 70$. Maka hipotesis tindakan dalampenelitian ini telah tercapai yaitu penerapan model pembelajaran mind mapping meningkatkan hasil belajar siswa materi koperasi di kelas IV 13 poasia kota kendari.

\section{Simpulan}

Berdasarkan hasil penelitian dan pembahasan pada setiap siklus dari penelitian ini, maka dapat disimpulkan bahwa Penerapan model pembelajaran mind mapping dapat meningkatkan hasil belajar IPS pada materi koperasi pada siswa kelas $\operatorname{IV}_{\mathrm{B}} 13$ poasia kota kendari. Hal ini dapat dilihat pada peningkatan hasil belajar siswa, pada siklus I rata-rata hasil belajar siswa adalah $68,83 \%$ dengan ketuntasan klasikal sebesar 66,66\% sedangkan pada siklus II rata-rata hasil belajar siswa adalah 80,2\% dengan ketuntasan klasikal mencapai 87,5\%.

\section{Daftar Pustaka}

Hamid, Aqib 2007. Statistika Dasar. Jakarta: Universitas Terbuka.

Hendriana, Heris \& Utari Soemarno. 2014. Penilaian Pembelajaran Matematika. Cimahi: PT Refika Adi Tama. 
Jurnal Ilmiah Pembelajaran Sekolah Dasar

Volume 1 Nomor 2 - Agustus 2019,e-ISSN 26560402

Available online at:http://ojs.uho.ac.id/index.php/jipsd

Kurniasih, Imas \& Berlin Sani. 2014. Teknik \& Cara Mudah Membuat Penelitian Tindakan Kelas Untuk Pengembangan Profesi Guru. Solo: Kata Pena.

Kusumah, Wijaya \& Dedi Dwitagama. 2012. Mengenal Penelitian Tindakan Kelas. Jakarta Barat: PT. Indeks.

La Iru \& La Ode Safiun Arihi. 2012. Pendekatan, Metode, Strategi, dan Model-Model Pembelajaran. Yogyakarta: Multi Presindo.

Susanto, Ahmad. 2015. Teori Belajar \& Pembelajaran di Sekolah Dasar. Jakarta. Kencana

Trianto. 2013. Mendesain Model Pembelajaran Inovatif-Progresif. Jakarta: Prenada Media Group. 